\title{
PENGARUH GAYA MENGAJAR DAN MOTIVASI BELAJAR TERHADAP HASIL BELAJAR LAY UP SHOOT
}

\author{
1)Gilang Ramadan, ${ }^{2)}$ Dedi Iskandar \\ ${ }^{1,2}$ Pendidikan Jasmani kesehatan dan rekreasi, STKIP Muhammadiyah Kuningan \\ email: gilang.ramadan@upmk.ac.id
}

\begin{abstract}
The aim of this study was to determine the effect of Reciprocal teaching styles and teaching styles Exercise as well as learning motivation towards learning outcomes Lay UpShoot.The research was conducted on students and SMA Negeri 1 Cigugur. This study uses a treatment by the level of $2 \times 2$. The sample consisted of 28 students as well as students. The data analysis technique is a two-track analysis of variance (ANOVA) and then followed by Tukey's test at a significance level $\alpha=0$, 05. The results of this study indicate that (1). Value of learning outcomes Lay Up Shoot in the treatment higher Reciprocal teaching style with the results of $50 \%$ (14) above the average of the value style of teaching exercises that only 39.29\% (11) above average in SMA 1 Cigugur. (2). Value learning outcomes Lay Up Shoot in the treatment of Reciprocal teaching style of learning motivation high (A1B1)is higher than the value of teaching style Exercise high learning motivation (A2B1)in SMA Negeri 1 Cigugur. (3). Value learning outcomes Lay Up Shoot in the treatment of Reciprocal teaching style low learning motivation (A1B2)is lower than the value of teaching style Exercise low learning motivation (A2B2)in SMA Negeri 1 Cigugur.
\end{abstract}

Keyword: Reciprocal teaching styles, teaching styles Exercise, learning motivation

\begin{abstract}
Abstrak: Tujuan dari penelitian ini adalah untuk mengetahui pengaruh dari gaya mengajar Resiprokal dan gaya mengajar Latihan serta motivasi belajar terhadap hasil belajar Lay Up Shoot. Penelitian ini dilakukan pada siswa maupun siswi SMA Negeri 1 Cigugur. Penelitian ini menggunakan treatment by level 2 x 2. Sampel terdiri dari 28 siswa maupun siswi. Teknik analisis data adalah analisis varians dua jalur (ANAVA) dan selanjutnya dilanjutkan dengan uji Tukey pada tingkat signifikansi $\alpha=0$, 05. Hasil penelitian ini menunjukkan bahwa (1). Nilai hasil belajar Lay Up Shoot pada perlakuan gaya mengajar Resiprokal lebih tinggi dengan hasil 50\% (14 orang) di atas rata-rata dari nilai gaya mengajar Latihan yang hanya $39,29 \%$ (11 orang) di atas rata-rata di SMA Negeri 1 Cigugur. (2). Nilai hasil belajar Lay Up Shoot pada perlakuan gaya mengajar Resiprokal motivasi belajar tinggi $\left(\mathrm{A}_{1} \mathrm{~B}_{1}\right)$ lebih tinggi dari nilai gaya mengajar Latihan motivasi belajar tinggi $\left(\mathrm{A}_{2} \mathrm{~B}_{1}\right)$ di SMA Negeri 1 Cigugur. (3). Nilai hasil belajar Lay $U p$ Shoot pada perlakuan gaya mengajar Resiprokal motivasi belajar rendah $\left(\mathrm{A}_{1} \mathrm{~B}_{2}\right)$ lebih rendah dari nilai gaya mengajar Latihan motivasi belajar rendah $\left(\mathrm{A}_{2} \mathrm{~B}_{2}\right)$ di SMA Negeri 1 Cigugur.
\end{abstract}

Kata kunci: Gaya Mengajar Resiprokal, Gaya Mengajar Latihan, motivasi belajar

\section{PENDAHULUAN}

Olahraga merupakan aktivitas manusia yang sangat berpengaruh terhadap kesehatan bagi para pelakunya baik itu olahraga yang dilakukan secara rekretif, kompetitif maupun dengan tujuan prestasi. Olahraga ditanah air dari waktu kewaktu mengalami perubahan seiring dengan perkembangan zaman di mana pola hidup dan pola pikir manusia semakin berkembang pula, sehingga memberikan konsekuensi perubahan perilaku kearah yang lebih meningkat lagi. Perilaku yang 
dimaksud adalah tindakan nyata terhadap usaha kesegaran jasmani dan olahraga.

Karena olahraga adalah bagian dari pendidikan maka dalam meningkatkan mutu pendidikan sebagai proses pembinaan manusia yang berlangsung sepanjang hayat, oleh karena itu pentingnya peranan pendidikan jasmani untuk merangsang pertumbuhan dan perkembangan manusia mutlak di perlukan. Pendidikan jasmani merupakan wahana yang mampu mendidik manusia untuk mendekati kesempurnaan hidup yang secara alamih dapat memberikan kontribusi nyata terhadap kehidupan sehari-hari.

Gaya mengajar yang dilakukan oleh guru dalam praktek pendidikan jasmani cenderung tradisional. Model metode pembelajaran berpusat pada guru (teacher centered) dimana para siswa melakukan latihan fisik berdasarkan perintah yang ditentukan guru. Latihan-latihan tersebut hampir tidak pernah dilakukan oleh siswa sesuai dengan inisiatif sendiri (student centered). Guru pendidikan jasmani tradisional cenderung menekankan pada penguasaan keterampilan cabang olahraga. Dalam pendekatan ini, guru menentukan tugas-tugas ajarnya kepada siswa melalui kegiatan fisik tak bedanya seperti melatih suatu cabang olahraga.

Berdasarkan hasil observasi sebelumnya terhadap pembelajaran penjas dengan materi lay up shoot pada siswa SMA N 3 Kuningan menunjukan bahwa metode pembelajaran yang dilakukan lebih sering menggunakan metode permaianan sehingga capaian pembelajran yang diharapkan kurang maksimal. Guru kurang memiliki peranan yang sesuai karena sifatnya hanya mengawasi sementara pembenaran terhadap gerakkan yang dilakukan oleh siswa kurang mendapat perhatian sehingga siswa kurang menguasai teknik dasar yang baik.
Sehubungan dengan hal itu, maka untuk melakukan proses pembelajaran lay up shoot, dipilih gaya pembelajaran yang tepat dan mudah diterapkan kepada siswa, sehingga berbagai aktivitas gerak latihan lay up shoot dapat dikuasai dengan baik dan benar. Gaya mengajar Latihan dan gaya mengajar resiprokal merupakan bagian dari gaya pembelajaran yang digunakan dalam pembelajaran lay up shoot dalam bola basket. Mata pelajaran pendidikan jasmani sebagai salah satu pelajaran normatif yang wajib di ajarkan di sekolah sangat memiliki peran penting dan sentral dalam pembentukan manusia Indonesia seutuhnya.

Motivasi bertalian dengan suatu tujuan sebagai contoh seseorang pemain basket rajin berlatih tanpa mengenal lelah, karena mengharapkan akan mendapat kemenangan dalam pertandingan yang akan di lakukannya. Dengan demikian maka motivasi itu mempengaruhi adanya kegiatan, sehubungan dengan hal tersebut ada 3 fungsi motivasi, yakni: (1) Mendorong manusia untuk berbuat, (2) Menentukan arah perbuatan, (3) Menyeleksi perbuatan.

Dalam kegiatan belajar mengajar tetap penting keberadaannya karena kemungkinan besar keadaam siswa dinamis, berubah - ubah. Motivasi intrinsik dapat tumbuh \& berkembang pada diri siswa di mulai dari motivasi ekstrinsik, serta mungkin juga komponen - komponen dan dalam proses belajar mengajar ada yang kurang menarik bagi siswa, sehingga diperlukan motivasi ekstrinsik. Motivasi belajar siswa memiliki indikator-indikator sebagai berikut: (1) keinginan berhasil dalam belajar, (2) keinginan untuk berprasangka dalam belajar, (3) keinginan untuk melakukan pekerjaan yang menantang, (4) keinginan untuk giat belajar, (5) keinginan untuk bekerja mandiri bertanggung jawab. 


\section{METODE PENELITIAN}

Metode penelitian yang digunakan dalam penelitian ini adalah metode eksperimen, dengan disain treatment by level $2 \times 2$. Dan untuk menganalisis data yang terkumpul, digunakan teknik analisis varians (ANAVA) dua jalur pada taraf signifikan $\alpha=0,05$. Penelitian ini berdasarkan prinsip penelitian eksperiment yaitu dengan adanya perakuan yang diberikan (treatment). Variable terikat adalah hasil belajar lay up shoot, sedangkan perlakuan yang diberikan dengan gaya mengajar resiprokal dan gaya mengajar latihan dan yang ditinjau dari motivasi belajar tinggi dan motivasi belajar rendah. Sesuai dengan permasalahan, maka desain penelitian adalah disain treatment by level 2 $x$ 2. Rancangan by level adalah unit-unit eksperimen dikelompokan ke dalam sel-sel sedemikian rupa secara acak, sehingga unitunit ekperimen dalam setiap sel bersifat homogen. Adapun rencangan penelitian seperti terlihat pada table di bawah ini:

Tabel 1 Rancangan Penelitian By Level 2x2

\begin{tabular}{|c|c|c|}
\hline Gaya Mengajar (A) & $\begin{array}{l}\text { Gaya Mengajar } \\
\text { Resiprokal }\left(\mathrm{A}_{1}\right)\end{array}$ & $\begin{array}{c}\text { Gaya Mengajar } \\
\text { Latihan }\left(\mathrm{A}_{2}\right)\end{array}$ \\
\hline \multicolumn{3}{|l|}{ Motivasi Belajar (B) } \\
\hline Motivasi Belajar tinggi $\left(\mathrm{B}_{1}\right)$ & $\mathrm{A}_{1} \mathrm{~B}_{1}$ & $\mathrm{~A}_{2} \mathrm{~B}_{1}$ \\
\hline Motivasi Belajar rendah $\left(\mathrm{B}_{2}\right)$ & $\mathrm{A}_{1} \mathrm{~B}_{2}$ & $\mathrm{~A}_{2} \mathrm{~B}_{2}$ \\
\hline
\end{tabular}

\section{HASIL DAN PEMBAHASAN}

Berdasarkan pelaksanaan hasil penelitian dapat diperoleh beberapa temuan sebagai berikut:

1. Secara keseluruhan, hasil hasil belajar Lay Up Shoot melalui penerapan gaya mengajar resiprokal lebih baik daripada gaya mengajar latihan.

Hasil belajar Lay Up Shoot merupakan salah satu pola gerak dasar yang sangat penting dalam bolabasket. Setiap siswa harus benar-benar menguasai akan pola gerak dasar Lay Up Shoot. Untuk itu dibutuhkan gaya mengajar yang cocok di dalam mengajar Lay Up Shoot. Kedua gaya mengajar ini mempunyai tujuan yang sama yaitu meningkatkan hasil belajar Lay $U p$ Shoot yang mana motivasi belajar tersebut sangat menunjang untuk mendapatkan hasil belajar Lay Up Shoot yang baik, akan tetapi masing-masing gaya mengajar tersebut memiliki perbedaan dalam segi pelaksanaannya.

Hasil analisis gerak di atas diperkuat oleh hasil perhitungan analisis varians tentang perbedaan keefektifan antara kedua gaya mengajar secara keseluruhan, yakni;

Tabel 1 Rancangan Penelitian By Level 2x2

\begin{tabular}{cccc}
\hline Gaya & \multicolumn{3}{c}{ Hasil } \\
\cline { 2 - 4 } Mengajar & $\begin{array}{c}\text { Di Bawah } \\
\text { rata-rata }\end{array}$ & Rata-rata & $\begin{array}{c}\text { Di Atas } \\
\text { rata-rata }\end{array}$ \\
\hline Gaya & $35,71 \%$ & $14,29 \%$ & $50 \%$ \\
\hline
\end{tabular}




\begin{tabular}{lccc}
\hline $\begin{array}{l}\text { mengajar } \\
\text { Resiprokal }\end{array}$ & (10 orang) & (4 orang) & (14 orang) \\
\hline Gaya & $14 \%$ & $28,57 \%$ & $39,29 \%$ \\
mengajar & (9 orang) & $(8$ orang) & $(11$ orang) \\
Latihan & & & \\
\hline
\end{tabular}

maka dapat disimpulkan bahwa secara keseluruhan gaya mengajar resiprokal lebih baik dari pada gaya mengajar latihan terhadap hasil hasil belajar Lay Up Shoot.

2. Bagi siswa yang memiliki motivasi belajar tinggi, hasil belajar Lay $U p$ Shoot melalui penerapan gaya mengajar resiprokal lebih baik daripada gaya mengajar latihan.

Bagi siswa yang memiliki motivasi belajar tinggi hal yang demikian justru akan dapat mengembangkan kemampuannya terhadap pencapaian peningkatan keterampilan, karena mereka lebih tertarik untuk melakukan yang lebih jauh. Dengan kata lain siswa yang melakukan gaya mengajar latihan tidak dipengaruhi oleh faktor eksternal. Bagi siswa yang memiliki motivasi belajar tinggi, latihan tersebut merupakan kegiatan yang biasa serta tidak mempunyai tantangan yang tinggi, karena menurutnya latihan tersebut sangat mudah dan sederhana sehingga tidak menimbulkan motivasi yang tinggi serta unsur kompetisi sangat kecil dalam meningkatkan motivasi belajar, dengan demikian hasil yang akan dicapai juga tidak seperti yang diharapkan. Dengan kata lain, belajar dengan penerapan gaya mengajar latihan bagi siswa yang memiliki motivasi belajar tinggi kurang menimbulkan unsur motivasi serta kompetisi.

Hasil analisis gerak di atas diperkuat oleh hasil uji lanjut kelompok motivasi belajar tinggi yang diajar dengan gaya mengajar resiprokal dibandingkan dengan kelompok motivasi belajar tinggi yang diajar dengan gaya mengajar latihan, hasilnya; $\mathrm{Q}$ hitung $=$
$5,53>\mathrm{Q}_{\text {tabel }}=3,79$. Dengan kata lain bahwa bagi siswa yang memiliki motivasi belajar tinggi, keefektifan gaya mengajar resiprokal lebih baik secara nyata dibandingkan dengan gaya mengajar latihan. Dengan demikian berdasarkan pembahasan hasil penelitian, maka dapat direkomendasikan bahwa bagi siswa yang memiliki motivasi belajar tinggi, gaya mengajar resiprokal lebih cocok diterapkan dalam meningkatkan hasil belajar Lay $U p$ Shoot.

3. Bagi siswa yang memiliki motivasi belajar rendah, hasil belajar Lay Up Shoot melalui penerapan gaya mengajar latihan lebih baik daripada gaya mengajar resiprokal.

Gaya mengajar ini dilakukan tanpa bantuan teman atau partner, artinya melakukan suatu kegiatan berdasarkan keinginan serta kemampuannya sendiri. Dengan kata lain siswa belajar sesuai irama dan kemampuannya sendiri tanpa kontrol batas waktu serta kemampuannya, dan hal ini tidak di pengaruhi oleh faktor lingkungan. Bagi siswa yang memiliki motivasi belajar rendah, belajar seperti ini merupakan kegiatan yang sangat disenangi, karena menurutnya belajar tersebut gerakan-gerakannya tidak terlalu diperhatikan sehingga siswa melakukan hanya menurut keinginannya saja.

Dengan kata lain, berlatih dengan penerapan gaya mengajar latihan bagi siswa yang memiliki motivasi belajar rendah lebih merangsang timbulnya gairah untuk mencapai tingkat otomatisasi gerakan Lay Up Shoot. Sedangkan belajar dengan 
penerapan gaya mengajar resiprokal siswa yang memiliki motivasi belajar rendah, kurang merangsang timbulnya gairah serta motivasi dalam usaha pencapaian otomatisasi gerakan Lay Up Shoot.

Hasil analisis gerak di atas ditunjang oleh hasil uji lanjut kelompok motivasi belajar rendah yang diajar dengan gaya mengajar latihan dibandingkan dengan kelompok motivasi belajar rendah yang diajar dengan gaya mengajar resiprokal, hasilnya; $\mathrm{Q}$ hitung $=2,19<\mathrm{Q}$ tabel $=3,79$. Dengan kata lain bahwa bagi siswa yang memiliki motivasi belajar rendah, gaya mengajar latihan dan gaya mengajar resiprokal tidak memberikan keefektifan hasil yang signifikan terhadap hasil belajar Lay Up Shoot. Dengan demikian berdasarkan pembahasan hasil penelitian, maka bagi siswa yang memiliki motivasi belajar rendah, kedua gaya mengajar cocok diterapkan dalam meningkatkan hasil belajar Lay Up Shoot.

\section{SIMPULAN}

Berdasarkan hasil analisis data, hasil pengujian hipotesis dan hasil pembahasan penelitian yang telah diperoleh maka dapat dijelaskan beberapa kesimpulan, implikasi penelitian dan saran sebagai berikut:

1. Hasil hasil belajar lay up shoot bagi kelompok siswa yang diajar dengan gaya mengajar resiprokal secara keseluruhan lebih baik dibandingkan dengan kelompok siswa yang diajar dengan gaya mengajar latihan.

2. Bagi siswa yang memiliki motivasi belajar tinggi, hasil hasil belajar lay up shoot melalui penerapan gaya mengajar resiprokal lebih baik dibandingkan dengan gaya mengajar latihan.

3. Bagi siswa yang memiliki motivasi belajar rendah, hasil hasil belajar lay up shoot melalui penerapan gaya mengajar latihan lebih baik dibandingkan dengan gaya mengajar resiprokal.

\section{DAFTAR RUJUKAN}

Abdulkadir Ateng. 1993 Pendidikan Jasmani di Indonesia. Jakarta: Guna Prakasa Jati.

Abraham H Maslow. 1970 Motivation and Personality. New York: Haper \& Row Publisher.

Allen L. Edwards. 1985 Experimental Design in Physical Research. Fifth Edition. New York: Harper \& Row, Inc.

Anita. E. Woolfolk. 1993 Educational Psychology. Needham Heights, MA Allyn and Bacom, Inc.

Benyamin. S.Bloom. 1981 Taxonomy of Education Objectives. New York: Longman.

Frank M. Verducci. Measurement Concepts in Physical education. St.Louis Missouri: Mosby Company, 1980.

Fred N. Kerlinger. 1995 Azas-Azas Penelitian Behavioral: Terjemahan Landung R. Simatupang. Yogyakarta: Gajah Mada University Press.

Gerhard Stocker, et al. 1984Bola Basket: Dari Permainan Sampai pertandingan. Terjemahan Agus Setiadi. Jakarta: Gramedia.

Harsono. 1988 Coaching dan Aspek Aspek Psikologi Dalam Coaching. Jakarta: cv.Tambak kusuma.

Leslei J. Bringgs (Ed). 1979Instructional Design Principles and Applications. Englewood Cliffs, New Jercey: Educational Publications, Inc.

Martinis Yamin, 2008 Paradigma Pendidikan Konstruktivistik, Implementasi KTSP \& UU.No 14 tahun 2005 tentang Guru dan Dosen. Jakarta: GP Press. 
Muhibbin Syah. Pengertian Belajar, http//www.ut.ac.id/olsupp/FKIP/pgsm 3803/hakekat. Htm. 1989 Psikologi Pendidikan Suatu Pendekatan baru. Bandung: Penerbit PT. Rosdakarya.

Musska Mosston and Sara Asworth. 1994Teaching Physical Education. New York: Mac Millan college Publising Inc.

Nana Sudjana. 1994 Penilaian Hasil Proses Belajar Mengajar. Bandung: Rosdakarya.

Ngalim Purwanto. 1995 Psikologi Pendidikan. Bandung: Remaja Rosdakarya.

PB.PERBASI. 2006 Bola Basket Untuk semua. Jakarta: Bidang III PB. PERBASI.

Pulungan, Denggan. 2013 Gaya Mengajar Dan Motivasi Belajar Terhadap Hasil Belajar
Forehand Groundstrokes, Tesis. jakarta: PPs UNJ 2013. 1989 Kondisi Belajar dan Teori Pembelajaran, Alih bahasa Munadir. Jakarta: Ditjen Dikti Depdikbud.

Rusli Lutan. 2000 Strategi Belajar Mengajar Penjaskes. Jakarta: Depdiknas, Ditjen Dikdasmen.

s, Ega Trina. 2013 Strategi Pembelajaran Pendidikan Jasmani. Bandung: Alfabeta.

Sardiman. 2008 Interaksi \& motivasi Belajar Mengajar. Jakarta: PT. Raja Grafindo Persada.

Syaiful Bahri Djamarah. 2008 Psikologi Belajar Edisi II. Jakarta: Rineka Cipta.

Toeti Soekamto, Udin Sarifudin Winataputra. 1997 Teori Belajar dan Model-Model Pembelajaran. Jakarta, PAU Ditjen Dikti Depdikbud. 